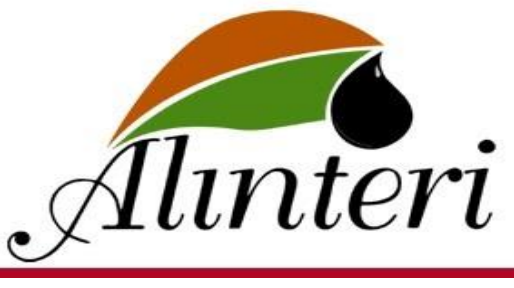

\title{
DEMOKRASI BAĞLAMINDA REFERANDUM UYGULAMASI: TÜRKİYE ÖRNEĞİ
}

\section{Referendum in the Context of Democracy: Turkey Example}

\author{
Hüseyin SEVINÇ⿻* \\ Bitlis Eren Üniversitesi, Ahlat Meslek Yüksekokulu, Bitlis, Türkiye.
}

\section{Ö Z}

\begin{abstract}
Tarihsel süreç içerisinde temsili demokrasinin karşılaşmış olduğu sorunların çözümü için önerilen doğrudan demokrasi araçlarından en önemlisi referandumlardır. Referandum bağlamında öne çıkan ülkeler ise Amerika Birleşik Devletleri ve İsviçre'dir ve bunun dışında pek çok ülkede referandum aracı kullanılmakla birlikte kullanımı tamamen ülkelerin kendi toplumsal ve siyasal kültür özelliklerine göre değişmektedir. Bundan dolayı referandum noktasında belli bir uygulama standardından bahsetmek mümkün değildir. Son yıllarda referandum uygulamalarının dünya genelinde hızlı bir şekilde arttığı gözlemlenmektedir. Bununla birlikte özellikle Sovyetler Birliği’nin dağılmasından sonra Doğu Avrupa ve Latin Amerika ülkelerinin yeni anayasa oluşturma süreçlerinde referandum kavramına yer vermeleri ve anayasalarını referandum yoluyla kabul etmeleri demokratikleşen veya demokratikleşme çabası içerisinde olan ülkelerin referandum yoluyla toplumsal mutabakat ve meşruiyet aramaları yaygın uygulama haline gelmiştir. Referandumların bu kadar yaygın uygulama alanı bulması referandum ile ilgili yayınların artmasını sağlamış ve sonuç olarak da referandum üzerine çalışanlar ve politikacılar tarafından referandumlar, sorunların çözümü için iyi bir uygulama aracı haline dönüşmüştür. Yapılan çalışmada ilk olarak demokrasi kavramından bahsedilmiştir. Demokrasi kavramı tarihsel süreç içerisinde doğrudan ve temsili demokrasi başlıkları çerçevesinde ele alınmıştır. Sonrasında referandum kavramı teorik açıdan incelenmiştir. Sonraki bölümde Türkiye'de demokrasinin gelişim süreci ele alınmıştır. Çalışmanın son bölümünde Türkiye'de 1961 yılından itibaren yapılmış olan yedi referandum değerlendirilmiştir. Sonuç olarak referandumun hem demokrasinin hem de hem de siyasetin bir uygulama aracı olabileceği gözlemlenmiştir. Bu nedenden dolayı referandumun demokrasinin bir aracı ve demokratikleşme sürecinin bir safhası olarak değerlendirebilmek için gündem konusunun belirlenmesi ve şekillenmesi aşamalarında temsilcilerin ve seçmenlerin karşılıklılık ilişkisi çerçevesinde sürece dâhil olmaları gerekmektedir. Bunun aksine bir süreçte gerçekleşen referandum için demokrasinin bir uygulama aracı yerine siyasetin bir uygulama aracı olarak bakmak daha anlamlı olacaktır.
\end{abstract}

Anahtar Kelimeler: Referandum, Demokrasi, Doğrudan Demokrasi, Temsili Demokrasi.

\begin{abstract}
A B S T R A C T
Referendums are the most important tools of the direct democracy in order to solve the problems of representative democracy that faced in historical process. United States of America and Switzerland stand out in the context of the referendum and apart from these countries referendum is used by many countries but the usage of referendum depends on the social and political cultural characteristics of the countries. Therefore, it is not possible to talk about a certain implementation standard at the referendum point. In recent years, it has been observed that referendum practices have increased rapidly around the world. At the same time, especially after the dissolution of the Soviet Union, Eastern European and Latin American countries include the concept of referendum in the process of creating a new constitution and adopt their constitutions through referendum, and the democratizing countries or those who are trying to democratize seek social consensus and legitimacy through referendum. The widespread use of referendums has led to an increase in publications about the referendum and as a result, referendums by those working on the referendum and politicians have turned into a good practice tool for solving problems. Firstly, the concept of democracy was mentioned in the study. The concept
\end{abstract}

\footnotetext{
* Sorumlu yazar/Corresponding author

E-mail: hsevinc1313@gmail.com
} 
of democracy has been discussed in the historical process within the framework of direct and representative democracy titles. After then the concept of referendum was examined theoretically. The next section focuses on the development of the democracy in Turkey. In the last part of the study seven referendums that made in turkey since 1961 is evaluated. As a result, it has been observed that the referendum can be a tool for both democracy and politics. For this reason, in order to evaluate the referendum as an instrument of democracy and a phase of the democratization process, representatives and voters should be involved in the process of determining and shaping the agenda subject within the framework of reciprocity. On the contrary, it would be more meaningful to look at the referendum held in a process as an implementation tool of politics rather than as a tool of implementation of democracy.

Keywords: Referendum, Democracy, Direct Democracy, Representative Democrasy.

Please cite this paper as follows/Atıf için:

Sevinç, H. (2021). Demokrasi Bağlamında Referandum Uygulaması: Türkiye Örneği. Alinteri Sosyal Bilimler Dergisi, 5(1): 29-50.

\section{GíRiş}

Demokrasi kavramı Antik Yunan medeniyetinden günümüze değişik formları ile nihayetinde mevcut en iyi yönetim biçimi olarak kabul görmektedir. Demokrasini uzun geçmişinde geçirmiş olduğu değişimlerle birlikte günümüzdeki uygulama çerçevesine kavuşmuştur ve bu süreçlerden geçerken ilk olarak kötü yönetim modeli olarak algılanmış sonrasında temsili demokrasi formuna dönüşmüş fakat burada da halk yığınlarının yönetimden bir şekilde uzaklaştırılması üzerine çalışmalar yapılmış ve sonuç olarak günümüzdeki eşit yurttaşlık temelinde demokrasi anlayışı kabul edilmiştir.

Tarihsel süreç içerisinde temsili demokrasinin karşılaşmış olduğu sorunların çözümü için önerilen doğrudan demokrasi araçlarından en önemlisi referandumlardır (Altman, 2011: 63; Kużelewska, 2009: 181; Qvortrup, 2018a). Referandum bağlamında öne çıkan ülkeler ise Amerika Birleşik Devletleri ve İsviçre'dir ve bunun dışında pek çok ülkede referandum aracı kullanılmakla birlikte bunun kullanımı tamamen ülkelerin kendi toplumsal ve siyasal kültür özelliklerine göre değişmektedir ve bu alanda belli bir uygulama standardından bahsetmek mümkün değildir.

Son yıllar gözlemlendiğinde referandum uygulamalarının dünya genelinde hızlı bir şekilde arttığı ve bununla birlikte özellikle Sovyetler Birliği’nin dağılmasından sonra Doğu Avrupa ve Latin Amerika ülkelerinin yeni anayasa oluşturma süreçlerinde referandum kavramına yer vermeleri ve anayasalarını referandum yoluyla kabul etmeleri (Hug, 2009: 251) demokratikleşen veya demokratikleşme çabası içerisinde olan ülkelerin referandum yoluyla toplumsal mutabakat ve meşruiyet aramaları yaygın uygulama haline gelmiştir. Referandumların bu kadar yaygın uygulama alanı bulması referandum ile ilgili yayınların² artmasını sağlamış ve sonuç olarak da referandum üzerine çalışanlar ve politikacılar tarafından referandumlar, sorunların çözümü için iyi bir uygulama aracı haline dönüşmüştür. Teknolojik gelişme ile birlikte ölçek sorununun aşılarak doğrudan demokrasi aracı olan referandumun bütün sorunların çözülmesinde kullanılan bir araç olması ileri vadede üzerinde düşünülebilecek bir konu haline dönüşebilir. Çünkü bir sistem ister demokratik ister antidemokratik olsun rejimin kendisi doğrudan demokrasi

\footnotetext{
${ }^{2}$ Suksi, Markku. 1993. Bringing in the People: A Comparison of Constitutional Forms and Practices of the Referendum.-Qvortrup, Mads. 2002. A Comparative Study of Referendums: Government by the People.Matsusaka, John G. 2005. IDirect Democracy Works.- Kessler, Anke. 2005. IRepresentative versus Direct Democracy: The Role of Informational Asymmetries.-Hamon, Francis. 1995. Le referendum. Etude comparative.-Cronin, Thomas E. 1989. Direct Democracy. The Politics of Initiative, Referen- dum and Recall. vb.
} 
araçlarının kullanımına etki edebilecek ihtimali bünyesinde barındırır. Doğrudan demokrasi araçları özelinde referandumlar demokratik olmayan rejimlerin kullanmış olduğu karakteristik bir araç olmasına rağmen konsolide olmuş demokrasiler referandumları kötüye kullanmazlar (Altman, 2011: 65-66). Gerçek demokrasilerin altında yatan temel mantık vatandaşlarının özgürce örgütlenmesine, harekete geçmesine ve hükümete değişiklikler (veya statükonun sürdürülmesi) için baskı yapmasına izin vermesidir. Demokrasilerde, vatandaşların eksiklikleri nedeniyle hükümetlerini etkileme, kınama ve cezalandırma olasılığı daha yüksektir ve hükümetin görev süresi seçim siyasetine bağlıdır. Demokratik olmayan sistemlerde ise bahsedilen durumlar tersine işlemektedir. Bundan dolayı referandumlar yukarıdan aşağıya dayatılma şeklinde kendini gösterir. (Altman, 2011: 88).Sonuç olarak doğrudan demokrasinin bir aracı olan referandum konsolide olmuş demokrasilerde vatandaşların siyasete katılımını arttıran ve alınan kararlarda söz sahibi olmasını sağlayan bir işlev görmektedir. Otokratik yapılarda ise referandumlar demokrasiyi geliştiren bir araç olmaktan ziyade iktidarın siyaset aracı konumundadır. Bununla birlikte otokratik rejimlerde referandumun kullanılması aslında demokratik bir sürecin yanılsamasının yaratılması ile motive edilerek rejim ile nüfus arasında psikolojik ve duygusal bir bağın kurulmasını amaçlar.

\section{YÖNTEM}

$\mathrm{Bu}$ çalışmanın temel amacı referandumların demokrasi bağlamında incelenmesidir. $\mathrm{Bu}$ inceleme yapılırken ilk bölümde demokrasi kavramına tarihsel perspektifte bakıldıktan sonra demokrasi çeşitleri anayasal sınıflandırma çerçevesinde incelenmiştir. İkinci bölümde ise referandum kavramı hem anlamsal açıdan hem de tarihsel yolculuğu çerçevesinde incelenerek demokrasi içerisindeki yeri çerçevesinde ele alındıktan sonra Türkiye'deki referandum uygulamaları önceki bölümler çerçevesinde değerlendirilmiştir.

\section{DEMOKRASI}

Antik çağdaki doğuşundan günümüze kadar "demokrasi” kavramı siyasi tartışmaların merkezinde olmakla birlikte toplumsal süreçlerde meydana gelen değişikliklerle birlikte mevcut süreçlere uyum sağlayarak kendini yeniden inşa etme özelliğine sahip olmuştur (Tosun, 2001: 95). Demokrasinin gerçek veya çıkış noktasındaki anlamı toplumsal yapıların ve koşulların sürekli değişmesi neticesinde mevcut anlamından uzaklaşarak üzerinde insanlık tarihi boyunca üzerinde yorum yapılan ve bu nedenle anlam erozyonuna uğrayan bir kavram halini almıştır (Aktan, 1997: 135).

Demokrasi kavramı Antik Yunan'da "demos" (halk) ve "kratos" (otorite) kelimelerinin birleşmesinden ortaya çıkmış ve sonra "democratia" sözcüğüne evrilmiş ve Türkçe'ye de Fransızca olan "démocratie” kelimesinden girmiştir (Schmidt, 2002: 13). Demokrasinin etimolojik kökeninde bulunan Demos, Antik Yunan'da belirli bir poliste (kentte) yaşayan vatandaşlar anlamı ile birlikte sıradan insanlar, alt tabaka ya da alt tabakadaki din adamlarına karşılık olarak kullanılmıştır. Kratos da güç ya da egemenlik anlamını taşıdığı gibi iktidar anlamında da kullanılabilmiştir (Miller, Coleman, Connolly, \& Ryan, 1994: 163). Kelime anlamı olarak halkın iktidarı veya egemenliği olarak ifade edilen demokrasi kavramı tarihsel bağlamda Antik Yunan site devletlerinde ortaya çıkmasına rağmen tarihsel bağlamda yaygın ve küresel kullanım ve anlamına modern devlet ile kavuşmuştur. 
Tarihsel süreç bağlamında Antik Yunan'da uygulanan demokraside halktan bahsederken yaşayan tüm nüfusun tamamı anlaşılmamalıdır. Antik Yunan'da halk denilince büyük bir köle nüfusunun dışlandığı azınlık elitleri anlamak gerekir. Demokrasinin uygulandığı Atina'nın nüfusu 350.000 civarında iken yurttaş olarak nitelendirilen erkeklerin sayısı 40.000 ile 45.000 arasında değişmekteydi. Yurttaş kavramı sınırlı sayıda olduğu için dönemin demokrasi anlayışı yüz yüze toplum modelini sergileyen cemaat demokrasisi olarak nitelendirilebilmekle birlikte belirtilen dönemde ayırt edici bir biçimde birey kavramından söz etmek mümkün değildi (Köker, 2008: 169).

Atina demokrasisinde yönetim halkın temsilci göndererek katılımı yerine halkın doğrudan katılımı ile gerçekleşmiştir. Doğrudan katılımı mümkün kılan ve temsilci eliyle yönetimi reddeden yapının temelinde halkın kamusal meselelere karşı yüksek duyarlılığının olması gerektiğine dair oluşan kanaattir. Bu bağlamda Atina demokrasisinin belirleyici özelliği, kamusal meselelerin özel hayattan önde olmasını ifade eden yurttaşlık erdemine sahip olmasidır (Held, 2006: 17).

Demokrasi uygulamalarında ortaya çıktığı yer olan Antik Yunan'dan günümüze bazı zorluklar yaşanmıştır. Bunun temel nedeni ortaya çıkışından itibaren birçok düşünür tarafindan demokrasinin erkek egemenliğine dayalı yoksul ve mülksüz olan toplumlar için geçerli bir yönetim modeli olarak ele alınmasıdır. Nitekim Aristoteles demokrasi ile oligarşi arasındaki ayrımı belirtirken malvarlığından yola çıkar. Aristoteles'e göre;

Oligarşi ile demokrasiyi birbirinden ayıran, servetin varlı̆̆ ya da yokluğudur. Esas nokta, siyasal erke sahip olmanın ekonomik erke ya da servete sahip olmaktan ileri geldiği yerde, kişilerin sayısı çok da olsa az da olsa, bunun oligarşi; mülkiyetsiz sınıf erke sahip olunca da bunun demokrasi olmasıdır (Aristoteles, 2010: 82).

Aristoteles, oligarşi-demokrasi ayrımını yaptıktan sonra demokrasinin doğasında her zaman için tehlike ihtimali olduğunu belirtir. Aristoteles'e göre yoksulların yönetiminin yoksulların çıkarına ait bir yönetime dönüşüp bozulması halinde yani demokrasilerde yönetime ilişkin özel eğitimi olmayan, sabıkalı, çapulcu insanların da yönetime gelme tehlikesi söz konusu olduğu için, demokrasi konusunda her zaman temkinli olmak gerekmektedir (Aristoteles, 2010: 54).

Platon, benzer bir tutumla demokrasiyi belli bir düzeni olmayan özgürlükler ve serbestlikler düzeni olarak nitelendirip demokrasiye olumsuz bir anlam yükler. Platon'a göre demokrasi; "alabildiğine zengin olmak isteğinin, doymak bilmez bir mal açlığının sonucudur” (Platon, 2001: 220). K1saca belirtmek gerekirse Antik Yunan'daki demokrasi algısı günümüzdeki demokrasi anlayışı ve uygulamalarından oldukça farklılık göstermektedir.

Antik Yunan'da etkili olan demokrasi düşüncesi kendisinden sonraki çağlarda tartışılan bir konu haline gelememiş ve uzun bir süre unutulmuştur. Ortaçağ boyunca demokrasi, bir yönetim biçimi olarak tartışılabilir malzeme olmaktan çıkmıştır. Tarihsel sürecin devamında Aydınlanma dönemi ile birlikte akılcı düşünmenin de etkisiyle 
demokrasi ve demokratik sözcükler nitelendirmiş oldukları bir toplum veya kurumun tasvip edildiğini ima eden sözcükler haline dönüşmeye başlamışlardır³ ${ }^{3}$.

$\mathrm{Bu}$ dönemde aristokrat sınıfla burjuva ve işçi sınıfı arasındaki ilişkileri yeni gelişimlere göre düzenleyen yasaların çıkarılması, eskiden farklı gelenek ve teamüllerin yaygınlaşmasına bağlı olarak meydana gelen sosyal değişmeler, çok sayıda insanın siyasal iktidara talip olmasına ortam hazırlamıştır. Demokrasi, zamanla aristokratik nitelikli olmuşsa da daha sonra burjuva sınıfının siyasal kararlarda gücünü belirginleştirmiştir. Böylece Avrupa burjuvazisi için dörtlü gelişme denklemi oluşmuştur. Zenginliği geliştiren ticaret, özgürlüğü gerektiren zenginlik ticareti kolaylaştıran özgürlük ve devletin gücünü arttıran ticarettir (Göze, 2017: 173-196).

Demokrasinin modern siyaset içerisine Amerikan ve Fransız devrimleriyle birlikte girdiği söylenebilir. Genel anlamda dünya özel anlamda Avrupa'da demokratik düşüncenin ve sistemin ivme kazanmasında Amerikan devriminin önemli bir rolü olmuştur. Amerika'da 1770'li yıllarda İngiltere hükümetine karşı başlayan başkaldırı ve bağımsızlıktan sonra imzalanan Virginia Haklar Bildirgesiyle insan hakları devlete karşı korunmuştur ve bu bildirgeyle ilk kez birey hakları devletin üzerinde tutulmuştur (Çaha, 2012: 233-234). Amerika'da liberal demokrasi anayasacılık kavramı üzerinden gelişmiştir. Bu düşüncenin temelinde yönetenlerin kendi otoritelerini belirme yetkisine sahip olmasının engellenmesi yatmaktadır. Amerikan kurucu babaları devletin yaratılmasının oluşturabileceği sakıncaların farkında oldukları için temelde anayasa ile devleti denetim altına almak istemişlerdir. Devletin anayasa ile denetim altına alınması için kuruluş aşamasında sıkı bir federalizm ve kuvvetler ayrılığı benimsenmiştir (Yayla, 2012: 13-16). Fransız Devrimi sırasında Rousseau'nun eserlerinin de etkisiyle şekillenen yeni anlayışa göre eğitim ve mülkiyet durumuna bakılmaksızın herkesin kamuyu ilgilendiren konularda iradesini ortaya koyma hakkı vardır (Uslu, 2014: 144). Bu anlayışa göre Fransız devrimi, mülkiyetten bağımsız bir demokrasi anlayışı geliştirmiştir. Fransız Devrimi aristokrasi ve ruhban sınıfı dışında kalan Üçüncü tabakanın ${ }^{4}$ belirtilen sınıfların ayrıcalıklarını ortadan kaldırma çabasıyla gerçekleşmiştir. Bu bağlamda devrim, din ve toprak temelindeki aristokratlığa ve soyluluğa son verdiği için tüm insanların vatandaşlık temelinde eşit olduğu düşüncesini geliştirmiştir (Çaha, 2012: 235).

Tarihsel bağlamda belirtilen süreçlerden geçen demokrasinin aynı zamanda kapitalizmin yükselişi ile birlikte burjuva sınıfının ortaya çıkıp güçlenmesi ve sivil toplum alanını geliştirmesi modern demokrasinin doğuşu açısından ayrı bir öneme sahiptir. Fakat asıl kabul gören anlayış demokrasinin teorik anlamda aydınlanma düşüncesinin ortaya çıkması fiiliyatta ise burjuvazinin gelişmesi neticesinde geliştiğidir.

\footnotetext{
${ }^{3}$ Ortaçağ' da ticaretin gelişmesiyle birlikte yükselen orta sınıflar, yönetimde söz sahibi olma taleplerini ortaya koymaya başlamıştır. Bu dönemde "kararların alınmasına katılma hakkı verilmeyenler, bu kararlara uymak zorunda değildir" şeklindeki görüş, gittikçe taraftar kazanmaya başlamıştır. Özellikle sosyal şartların doğurduğu ortamlarda tepkide bulunma, imtiyazlara karşı bir protesto şeklini almaya başlamıştır. Modern demokrasiye geçişin tohumu da aslında Ortaçağda tartışılan bu görüşün içinde saklıdır (Laski \& Strachey, 1962: 9-12).

${ }^{4}$ Dönemin Fransa'sında toplumsal tabakalar; ruhban, aristokrasi ve diğer tüm toplumsal sınıflar şeklinde dizayn edilmişti. Ruhban ve aristokrasi dışındaki sınıfa aynı zamanda Üçüncü Tabaka denilmekteydi ve burjuvazi de bu tabakanın bir parçasıydı (Uslu,2014:144).
} 
Aydınlanma düşüncesi ile birlikte yaygın ve ideal bir hal alan demokrasi düşüncesi hızlı bir biçimde yayılmış ve farklı demokrasi anlayışları ortaya çıkmıştır (Bulut, 2003: 70).

Tarihsel süreç çerçevesinden bakıldığında, demokrasi tarihsel gelişiminde statik olmak yerine kendini sürekli olarak yenileyen bir kavram olmuştur. Zaman içerisinde kendini yenileyen demokrasi kavramı toplumsal değişimler sonucunda ortaya çıkan sorunlarda kendi fonksiyonlarını devreye sokarak sorunsuz çözümler sunmuştur. $\mathrm{Bu}$ bağlamda Samuel Huntington da aynı şekilde demokrasi tarihini; "yavaş ve kesintisiz bir ilerleme olmayıp, ilerleyen geri çekilen, sonra toparlanan ve tekrar yükselen bir dalgalar dizisi" olarak sunmuştur (Huntington, 1993: 11-22). Referandumlarında demokratikleşme dalgalarına benzer bir çizgide ilerlediği ifade edilebilir. Nitekim referandumlar dalgalar halinde ele alındığında referandumların 1793 Fransız anayasa değişikliği ile başlayan süreçte artış eğiliminde olduğu söylenebilir. 19. Yüzyıl bütünüyle ele alındığında belirtilen dönemde birkaç referandum yapılmış olmasına rağmen asıl sıçrayış özellikle 20. Yüzyılın ikinci yarısından itibaren gerçekleşmiştir. 1990'lı yıllarda özellikle Sovyet rejiminin dağılması sonucu bağımsızlığını kazanan ülkelerde referandumların yapılmış olması dünya genelinde referandumların sayısını arttırmıştır. 2000'li yıllarda referandum sayısında çok fazla azalış olmamasına rağmen referandumların niteliği değişmeye başlamıştır. Belirtilen dönem aralığında anayasal referandumlar ağırlıklarını korumasına rağmen özel ve siyasal iktidarı güçlendirmeye yönelik referandumlarda (Örneğin 2015 Yunanistan ve 2016 Macaristan referandumları) artış olduğu gözlemlenmektedir (Qvortrup, 2018b: 263-267). Sonuç olarak kentleşme, coğrafi keşifler, Rönesans ve Reform, Aydınlanma çağı, ulus devletlerin doğuşu, milliyetçilik, liberalizm gibi tarihsel ve toplumsal dönüşümler demokrasinin gelişimini etkileyen önemli olgulardır. Bu değişimin en önemli özelliği ise "aktif halk" kavramının ortaya çıkmasıdır (Bostancı, 1995: 47).

\section{Demokrasi Türleri}

Günümüz dünyasında demokrasi üzerinde uzlaşılan bir tanımı olmayan kavramdır. Demokrasi genel anlamda vatandaşların ekonomik, sosyal ve politik haklardan yararlandığı ve yönetimin işleyişine dâhil olduğu popüler bir yönetim biçimi olarak tanımlanabilir. Bu anlamda demokratik uygulamaların çıkış noktası da siyasal ve kurumsal kararların alınması noktasında vatandaşların sürece daha çok dâhil edilmesini sağlamaktır. Demokratik sistemler halkın siyasal hayattaki etkinliği veya egemenliğin kullanılmasına göre doğrudan demokrasi, temsili demokrasi ve yarı doğrudan demokrasi şeklinde ayrıma tabi tutulmaktadır.

\section{Doğrudan Demokrasi}

Doğrudan demokrasi vatandaşların hükümet işlerine doğrudan aracısız katılmalarına dayanan yönetim biçimidir. Yaygın ve kabul edilen görüşe göre doğrudan demokrasinin ilk uygulamaları Antik Yunan şehir devletlerinde ve bunların en güçlü ve kurumsallaşmış olanı ise Atina'da görülmüştür (Heywood, 2014: 107).

Antik Yunan demokrasisini önceki dönemindeki rejimlerden ayıran temel unsur, toplumun (vatandaşların) polisin yönetiminde doğrudan söz sahibi olmasıdır. Köle, kadın ve yabancılar bir tarafa konunca geriye kalan tüm vatandaşlar arasında siyasi eşitlik söz konusudur. $\mathrm{Bu}$ çerçevede her vatandaş mecliste özgürce konuşma hakkına sahiptir. 
Vatandaşlar her gün bir arada toplandıkları toplantılarda fikirlerini özgürce paylaşıp, fikir alışverişinde bulunuyordu. Polislerde doğrudan demokrasinin görüldüğü öncelikli alan halk meclisleridir. Bununla birlikte, Beşyüzler meclisi (Boule) ve yargı gibi kurumlar aracılığıyla da insanlar siyasete dâhil edilmiştir. Yirmi yaşını dolduran her erkek vatandaş, halk meclisinin doğal üyesi sayılıyordu. Meclis yılda en az on, ortalama kırk kez toplanıyordu. Meclis; yasaları kabul eden, savaşa, barışa ve vergi toplanmasına karar veren organdır. Bütün yurttaşların bu meclise katılmasından dolayı Polis demokrasisine doğrudan demokrasi denmektedir (Kışlal1, 1984: 67).

Dörtyüzler meclisi, daha sonra beşyüzler meclisi olarak değişmiştir ve bu meclis her mahalleden 50 kişi olmak üzere on mahalleden seçilen 500 kişiden oluşmaktadır. Beşyüzler meclisinde özellikle soylular ağırlıktadır (Şenel, 2002: 119) ve halk meclisinin gündemini belirleme gibi bir takım görevleri bulunmaktadır. Polis'teki tüm yöneticiler ve kamu görevlileri bu meclise bağlı ve Polis'in bütün askeri unsurları bu meclisin denetimi altında bulunmaktadır (Kışlalı, 1984: 67).

Dönemin siyasal kurumları değerlendirildiğinde Antik Yunan Demokrasisinin bir azınlık demokrasisi olduğu görülür çünkü belirtilen dönem içerisinde siyasal haklara sahip olanların sayısı ile kapsamı oldukça dar tutulmuştur. Toplumdaki yurttaş kavramı nedeniyle toplumun sadece küçük bir kısmı belirtilen kurumlarda görev alabilmekte ve toplumun büyük bir kısmı bu siyasal haklardan mahrum kalmaktadır. Antik Yunan'daki demokrasi anlayışı aslında siyasal katılma olarak ele alınabilir ve modern anlamda bireyin iktidara, azınlığın çoğunluğa karşı korunması gibi çağdaş demokrasinin temel unsurlarını içermemektedir.

Doğrudan demokrasi, Atina demokrasi deneyiminden sonra uzun süre gündeme gelmemiştir. 17'nci yüzyıl ortalarında İngiltere'de başlayan düzenleyiciler hareketi (Levellers) modern anlamda doğrudan demokrasinin ilk savunucuları olarak kabul edilmektedir. Düzenleyiciler, halkın yöneticiler üzerinde daha fazla denetim sahibi olmalarını istiyorlardı. Bunun için de memurları, yargıçları hatta yerel rahipleri bile halkın seçmesini ve bunların gerektiğinde halk tarafından azledilebilmeleri (recall) gerektiğini savunuyorlardı (Cronin, 1989: 38). Demokrasi kavramı özellikle mutlak monarşilerin yıkılmasına neden olacak demokratik devlet tohumlarının atıldığı Fransız devrimi ile yeniden gündeme gelmiştir. Fransız Devrimi demokrasinin egemenlik boyutu ile yeniden tartışılmasını sağlamıştır ve burada öne çıkan iki teorem millet ve halk egemenliği olarak kendini göstermiştir (Gözler, 2014: 41).

Rousseau'nun savunduğu Halk Egemenliği ilkesi, doğrudan demokrasinin teorik kökenini oluşturmaktadır. Rousseau'ya göre egemenlik genel iradenin kullanılmasıdır ve genel iradenin ortaya çıkışı kanun ile geçekleşir. Kanunların yapılması ve böylece halk egemenliğinin gerçekleştirilmesi için başvurulacak tek yol doğrudan demokrasidir. Rousseau'ya göre halk egemenliği devredilemez. Bir siyasal rejimde eğer temsilciler halk adına hareket etme gerekçesiyle siyasi karar alma yetkisini ele geçirmişse artık orada demokrasi ve özgür halktan bahsedilemez (Gözler, 2007: 116).

Rousseau, küçük ve homojen toplumlarda doğrudan demokrasinin uygulanabileceğini savunmuştur (Setälä, 1999: 43). Toplum Sözleşmesi kitabında insanların doğrudan demokrasiyi uygulayabilecekleri ideal bir toplum tasavvurunu dile getirmiştir. Rousseau, "temsil” düşüncesine karşı çıkmaktadır. Rousseau'ya göre temsili 
demokrasiye geçildiği anda insanlar yasama özgülüklerini temsilcilerine devretmektedirler. Bu sakıncalı bir gelişmedir. Çünkü halkın onaylamadığı bir kanun, gerçek bir kanun değildir (Gözler, 1998: 99).

Modern anlamda doğrudan demokrasinin uygulandığı ve günümüzde de varlığııı devam ettiren ülke uygulamaları olduğunu belirtmek gerekir. Bunlar ABD"deki ' town meeting 'ler ve İsviçre'deki Landsgemeinde uygulamalarıdır (Gözler, 2014: 90). Kasaba toplantısı olarak çevrilebilecek townmeeting kurumu, Maine Massasachussets, New Hempshire, Vermont ve Connecticut Eyaletlerinde yer alan New England Kasabalarında (New England Towns) uygulanmaktadır (Lorch, 1992: 250-251). Buralarda kasaba sakinleri yılda bir kere toplanarak kasabanın idaresine dair kararlar almaktadır. Landsgemeinde ise benzer kurumun İsviçre'nin dağ kantonlarındaki uygulamasına verilen isimdir. Bu uygulamada da kanton halkı yılda bir kez toplanarak karar alır. $\mathrm{Bu}$ kurum, günümüzde sadece Glarus ve İç Appenzell İnnerhorden adındaki iki kantonda uygulanmaktadır (Gözler, 2014: 90).

\section{Temsili Demokrasi}

Antik Yunan kent devletlerinin yıkılması ile birlikte Avrupa'da kent devleti modelinden farklı olarak imparatorluk yapıları oluşmaya ve Roma İmparatorluğu'nun yıkılması ile birlikte yeni bir form olan feodal dönem yaşanmaya başlamıştır. XVI. ve XVII. yüzyıllarda ulus devlet düşüncesinin ortaya çıkıp gelişmeye başlaması beraberinde demokrasi düşüncesinin de canlanmasına neden olmuştur (Dahl, 2001: 271). Demokrasi düşüncesinin gelişimi Atina demokrasisinden düşünsel kaynağını almış olmasına rağmen kent devleti demokrasi modelinden ayrılarak kendine has kurumları beraberinde getirmiştir. Ülkelerin ölçek sorunu, yurttaş rollerindeki farklılaşma ve toplumsal değişimler nedenlerinden dolayı doğrudan demokrasinin uygulanması olanaksız hale gelmiş ve temsil kurumlarının oluşturulması zorunluluğu doğmuştur (Uygun, 2003: 116-118).

Temsil kavramı aslında demokratik yönetimlerin aksine ortaçağdaki anti demokratik monarşik yönetimlerin ekonomi ve savaş için oluşturdukları sistem olarak ortaya çıkmıştır (Uygun, 2003: 124). Temsil kurumu genel anlamda ortaçağda vergi ödenmesi, ordu kurulması ve kanunların yapılması için yüksek rütbeli din adamlarının ve halkın üst sınıfına mensup bazı yurttaşların olurunu almak için temsilcilerin seçilmeye başlamasıyla gelişen bir kurum olarak ortaya çıkmıştır (Dahl, 2001: 98-100).

Mutlak monarşilerin ulus devlet düşüncesi doğrultusunda sarsılmaya başladığı XVII. Yüzyıldan itibaren halk yığınlarının ülke yönetimine katılmalarına yönelik olarak Antik Yunan medeniyetinde olduğu gibi temkinli bir duruş sergilenmiştir. Temsil düşüncesi de belirtilen dönemin ürünüdür ve ilk uygulamalarında Monark'1n mutlak olan iktidarının sinırlandırılması ilk dönemlerde demokratik olmayan temsil kurumları ile fakat sonradan oy hakkının genişlemesi ile birlikte demokratikleşen temsili yapılarla yani parlamentolarla gerçekleşmiştir.

Temsili demokrasinin düşünsel temelini oluşturan düşünür ve fikirlere bakılırsa Montesquieu, kralın mutlak iktidarına karşı çıkmış ancak iktidarın paylaşılması noktasında halka sınırlı bir rol yüklemiştir. Aristo'nun karma anayasasına benzer bir biçimde halkın sınırlı katılımı ile yumuşatılmış bir anayasal monarşi, Montesquieu'nün 
idealidir. Düşünürün bu bağlamda demokrasiyi savunmadığı, aksine monarşik yönetimi keyfilik ve despotluktan kurtaracak çareler aradığı ileri sürülmüştür (Schmidt, 2002: 44).

John Stuart Mill, günümüz demokrasilerine daha fazla yaklaşan liberal demokratik yaklaşımıyla Montesquieu'den ayrılır. Monarşiyi ıslah etmeye yönelen Montesquieu'nün aksine Mill, demokratik bir sistem kurmak için siyasal kurumların reformdan geçmesini savunmuştur. Mill'in temel kaygısı devlet yönetimine yetersiz ve beceriksiz yöneticilerin gelmesi ile bilgisiz vatandaşların liyakatsizliğinin yani çoğunluğun tiranlığının engellenmesidir. Mill'e göre bunları gerçekleştirmenin yolu oy hakkının eğitim, bilgi ve zekaya göre verilmesinden geçmektedir (Schmidt, 2002: 96). Mill siyaset kurumunun demokrasi çerçevesinde örgütlenmesi taraftarıdır ve bireylerin özel hayatlarında mutluluğa ulaşabilmek için kendi kararlarını kendilerinin alması ne kadar doğal ise toplumsal hayatı düzenleyen siyasal kuralların yapım sürecine de vatandaş olarak katılmaları o kadar doğaldır. Mill, demokrasiyi savunurken halkın siyasal kararların yapım sürecine katılması bağlamında Antik Yunan'daki doğrudan katılım yerine, halkın kendi seçmiş olduğu temsilcileri aracılığıyla dolaylı olarak katılmasını uygun görmektedir. Mill'in temsili hükümet adını verdiği bu sistem vatandaş sayıları on binlerle ifade edilen site-devletlerinden farklı olarak milyonlarca vatandaşı bulunan ulus devletlerde demokrasinin uygulanması için mucizevi bir yöntemdir. Bu sayede halk iktidarın kendisinden kaynaklanması nedeniyle efendi pozisyonunu kaybetmemekle birlikte kendisinden çıkan vasıflı hizmetçiler istihdam etmektedir (Holden, 2007: 78).

Mill, iktidarın halktan kaynaklandığını kabul etmekle birlikte halkı oluşturan bütün bireylerin iktidarın oluşturulması sürecinde eşit derecede etkili olmasını kabul etmez. Ona göre iktidarı halk adına kullanacak olan hükümeti belirlemede halkın eğitimli ve eğitimsiz kesimi aynı söz hakkına sahip olursa bu toplumun geleceğinin cehaletin kaprislerine mahkûm etmek anlamına gelir ve bu nedenden dolayı Mill, elitist yaklaşımla çoğul oy sistemini önermiştir. Bu sistem sayesinde eğitimli olan kişiler hükümetin belirlenmesi sürecinde daha fazla etkili olabilecektir (Tannenbaum \& Schultz, 2015: 298). Mill belirtmiş olduğu düşünceleriyle demokrasiye elitist bir bakış açısıyla yaklaşmış ve demokrasinin göreceli homojen toplumlara özgü olduğunu vurgulamıştır (Reilly, 2003: 1). Bölünmüş toplumlarda temsili demokrasinin gelişmesi ve uzlaşmanın sağlanabilmesi için kurumsal düzenlemelerde yenileme yoluna gidilebilir. Gruplar arasında pazarlığı, iletişimi ve karşılıklı bağımlılığ 1 kolaylaştıran kurumsal düzenlemelerle birlikte firsat eşitliğinin gerçek anlamda sağlanması yoluyla eğitim seviyesinin yükseltilmesi belirtilen toplumlarda temsili demokrasinin kalitesini arttırmakla beraber devamlılığını sağlayabilir. Bu çerçevede Mill'in kaygı duyduğu çoğunluğun tiranlığı unsuru aşılabileceği gibi bölünmüş toplumlarda referandum gibi doğrudan demokrasi araçlarının kullanımında yüksek düzeyde hassasiyet oluşabilecektir.

Sonuç olarak halkın egemenliğini kendi seçmiş olduğu temsilciler aracılığı ile kullanmış olduğu demokrasi tipine temsili demokrasi denmektedir ve temsili demokrasinin düşünsel temeli ile birlikte teorik kökeni milli egemenlik ilkesine dayanmaktadır ve bu kavrama göre millet kendini oluşturan bireylerden ayrı ve soyut bir kavramdır. Millet bugünkü kuşakları kapsadığı gibi geçmiş ve gelecekteki kuşakları da kapsamaktadır ve bu nedenden dolayı milletin kendi adına iktidarı kullanacak temsilciler seçmesi ilkenin gereğidir. 


\section{Yarı Doğrudan Demokrasi}

Yarı doğrudan demokrasi, egemenliğin kullanılması bakımından halk ile temsilciler arasında paylaştırıldığı demokrasi biçimidir ve esasen temsili demokrasi ile doğrudan demokrasinin bir bileşimidir (Aktaş, 2015: 92). Sistemin işleyiş̧inde esasen egemenliğin kullanımı temsili demokrasideki gibi temsilcilere verilmektedir fakat bazı durumlarda referandum gibi araçlarla halkın egemenliği kullanması doğrudan sağlanmaktadır ve bu boyutuyla yarı doğrudan demokrasi aslında temsili demokrasinin bir türüdür.

Yarı doğrudan demokrasi, genel anlamda demokrasi sınıflandırması kapsamında temsili demokrasi içerisinde temsil edilmekle birlikte halk girişimi ve referandum gibi uygulamaları doğrudan demokrasinin günümüzdeki uygulama araçları olarak kabul edilir ve anayasa hukuku dışında ayrı demokrasi sınıflandırmasına tabi tutulmaz. Anayasa hukuku içerisinde demokrasi sınıflandırması içerisinde eğer temsili demokrasilerde doğrudan demokrasi araçlarına yer veriliyorsa bu sisteme yarı doğrudan demokrasi denilmektedir (Teziç, 1998: 244).

\section{REFERANDUM}

Referandum en basit tanımıyla siyasi bir konunun halk tarafindan oylanmasıdır. Köken olarak referandum Latince referre kelimesinden türetilmiştir ve geri getirmek veya geri göndermek anlamlarına gelir ((Qvortrup, 2015: 6). Referandum hakkında yapilan tanımlara bakılırsa; Referandum genel anlamıyla seçmenlerin bir tasarrufu hakkında önlerine gelen tasarrufu kabul etmek veya kabul etmemek suretiyle görüşlerinin doğrudan doğruya ifade etmelerini sağlayan bir araçtır (Suksi, 1993: 6). Diğer bir tanıma göre referandum yasama, anayasa veya iç ve dış politika ile ilgili önemli kararların alınmasında halka başvuru yöntemidir (Mishin, 1996: 149). Başka bir tanıma göre referandum bir yasama tasarrufu hakkında halkoyuna başvurma işlemidir (Kubalı, 1971: 278).

Referandum ile ilgili yapılan tanımlar genel anlamda birbirine benzemektedir ve varılan nokta hususunda üzerinde uzlaşılan bir kavramdır. Tanımlamalardan yola çıkarak referandum; seçme yeterliliğine sahip olan ülke vatandaşlarının yeni bir yasa, mevcut yasada değişiklik veya anayasa değişikliği gibi konularda kendi görüşlerini kabul veya red yönünde oy kullanarak açıklamaları ve bunu deklare etmeye yarayan araç olarak tanımlanabilir.

Referandumun teorik kökeni Jean Jacques Rousseau'nun Toplum Sözleşmesi kitabında bahsetmiş olduğu egemenliğin devredilmezliği kuramına dayandırılmaktadır (Gözler, 1998: 100). Referandum uygulamasını savunanlar, dayanak noktası olarak Rousseau'nun Toplum Sözleşmesi'nde bahsettiği egemenliğin devredilmezliği kuramını gösterirler. Egemenliğin devredilmezliği kuramına göre egemenlik halktadır ve genel iradeyi yansıttı̆̆ için başkasına devredilemez. Vekiller, halkın temsilcisi olamazlar ve sadece geçici işlerin yürütülmesini sağlayabilirler. Yasama yetkisi halkta olduğu için halkın onaylamadığı hiçbir yasa geçerli olamaz. Milletvekillerinin hazırladıkları yasalar bu nedenle halkoylamasına sunulmalıdır ve bu durum halkın teorik olarak sahip olduğu egemenliğini, fiilen de ele geçirmesinin tek yoludur (Gözler, 1998: 99).

Egemenlik hangi nedenlerden ötürü başkasina aktarılamazsa, yine aynı nedenlerden temsil de edilemez. Egemenlik başlıca genel isteme dayanır; genel istemse 
temsil olunamaz; ya genel istemdir, ya değildir. İkisinin ortası olamaz. Buna göre, milletvekilleri milletin temsilcileri değildirler ve olamazlar. Olsa olsa geçici işlerinin görevlileri olabilirler; hiçbir kesin karara da varamazlar. Halkın onamadığı hiçbir yasa geçerli değildir; yasa sayılmaz (Rousseau, 2006: 177).

Egemenlik, halk oyunun yürütülmesinden başka bir şey olmadığı için, bence hiçbir zaman başkasına geçirilemez; birleşimli (kolektif) bir varlık olan egemen varlı̆̆ da ancak yine kendisi temsil edebilir: İktidar başkasına geçebilir ama istem geçemez (Rousseau, 2006: 43).

Rousseau'ya göre yasalar genel iradeyi yansitmalı ve genel irade toplumun tümünün bünyesinde varlık bulur. Bu nedenden meclis tarafından bir yasa asla halkın onayını almadan geçerli hale gelemez ve bu durumda yapılan uygulama taslak niteliğinden öteye geçemez. Günümüz demokrasi anlayışında bu yöntem ancak referandum ile sağlanabilir. Fakat burada değinilmesi gereken önemli bir husus ise referandumların demokrasinin kalitesini arttırabileceği gibi popülist liderler veya otoriter ve yarı otoriter sistemlerde iktidarların politikalarını yürütme aracı olabilmesidir. Popülist eğilimlerin artmasına paralel olarak artan referandum kullanımı, içinde bulunulan yirmi yıllık süreçte aslında referandumların otoriter liderlerin yasama organını atlatma eğiliminin bir yansıması olup olmadığı sorununu ortaya çıkarmaktadır. Örneğin 2015 Yunanistan ve 2016 Macaristan'da yapılan referandumlara bakıldığında aslında referandumların yürütme hâkimiyetine kalkan olma özelliğinden sıyrılıp liberal olmayan hükümetlerin elinde bir silaha dönüştüğü söylenebilir. Demokratik olmayan sistemlerde referandumlar yapıldığı zaman iktidarın beklediği sonucun elde edileceği kesindir. Çünkü bu sistemlerde; yıldırma, kaynakların yetersiz dağılımı vb. hususlar nedeniyle demokrasi işlemez (Qvortrup, 2017: 141-148). Otokratik sistemlerde ise referandumlara ancak beklenen sonucun elde edilme ihtimali yüksekse gidilir ve bu sitemlerde Dahl'in belirtmiş olduğu demokratik değerlerden bir veya birkaçı eksik bir biçimde oylama yapılır. Kısaca ifade etmek gerekirse konsolide olmamış demokrasilerde referandumların kullanım amaçları; referandum yoluyla demokrasi yanılsaması oluşturmak, seçmen ile rejim arasındaki duygusal bağı pekiştirmek ve rejimin gücünü göstermek şeklinde sıralanabilir (Altman, 2011: 91-92).

\section{TÜRKIYY'DE DEMOKRASI KAVRAMI}

Türkiye' de demokrasinin gelişimine bakarken aslında Osmanlı döneminde ortaya çıkan modernleşme ve bunun ortaya çıkarmış olduğu seçkin yapı perspektifinde gelişen ve miras alınan bir demokrasi anlayışı görülmektedir. Osmanlı döneminde modernleşme hareketi Batı'dan farklı olarak aşağıdan yukarıya gelişen bir olgu olmak yerine direkt olarak toplum talebinin olmadığı yukarıdan aşağıya bir modernleşme olduğu görülmektedir. Osmanlı döneminde siyasal modernleşmenin öncüleri olan Genç Osmanlılar kuşağı özellikle 1876 yılında parlamentonun kurulmasına öncülük ederek modernleşmenin zihinsel dönüşümünü sağlamışlardır. Genç Osmanlılar kuşağının siyasal modernleşmede öncü konumda olmaları daha sonra Türk demokrasisinde de belirgin bir özelliğe sahip olan bir yapının miras kalmasına neden olmuştur. Belirtilen miras ise Türk modernleşmesinin ve bu bağlamda demokrasinin belli bir elit çekirdeğin yönlendirmesine bağlı olmasıdır. Belirtilen elit yapı modernleşmeyi toplumsal bir talep olmak yerine Batı kökenli olarak görürler ve bunun sonucu olarak demokrasinin sınırları da elitler tarafından 
çizilir. Modernleşme ve demokratikleşme sınırlarını belirleyen elitler bu faaliyetlerin yerine getirilmesini kendi iradesinde barındırır ki bu durum demokratikleşmenin hangi eksen ve koşullar içerisinde gerçekleşeceğinin ve topluma ifade edilmesinin elitler tarafından yapılmasını beraberinde getirir. Son olarak elitler modernleşme ve demokratikleşme sürecini tek başlarına başlatabilecek güce sahip olmadıklarını algıladıklarında siyasetin kontrol altında tutulması sağlayacak siyasal kadrolarla birleşir ve buna ilaveten ordunun ittifak unsuru olarak elitlerle bütünleşmesi sağlanır (Kahraman, 2008: 9-11). Türk demokrasisi incelenirken yukarıdan belirtilen çerçevede analiz ve değerlendirme yapılması Türkiye'de demokrasinin kesintiye uğrama nedenlerine açıklık getirmektedir.

Türkiye demokrasisinin elitist yapısı da göz önünde bulundurulduğunda; siyaset sınıfının kendi içerisinde ve topluma karşı demokratik bir tutum sergilememesi ile demokratik rejimin düzenli aralıklarla askeri darbeler yoluyla kırılması Türkiye demokrasisinin yarı demokratik olarak nitelendirilmesi gerektiği sonucunu doğurmaktadır. Bunun en somut göstergesi ise serbest seçimlerle seçilmiş hükümetlerin kendi iktidarlarını demokratik denge ve kontrol mekanizması içerisinde yer almayan kurumlar ve seçkinlerle paylaşmak zorunda olmasıdır (Çınar, 2014: 221). Seçkin yapının Osmanlı'dan miras alınması ve Osmanlı'da seçkin yapının zihinsel dönüşüm noktasında etkili olmasına rağmen siyasal pratikte ise seçkin yapı genel anlamda askeriyeden oluşmaktadır ve bu durum kendisini cumhuriyetin kuruluşunda da hissettirmiştir ki silahlı kuvvetler kendini bu anlamda sivil denetimin dışında bıraktığı gibi aynı zamanda sivil siyasetin izleyeceği çerçeveyi de belirleyecek bir noktada konumlandırmıştır. Belirtilen anlayış nedeniyle 1950'den itibaren yapılan serbest seçimler demokrasi noktasında belirleyici özelliğe sahip olamamıştır.

Türkiye demokrasisinde etkin olan elitist anlayış ve sorgulanmadan benimsenen Kemalist ideoloji, bir taraftan siyasal faaliyetleri değersizleştirirken diğer taraftan siyasetin belli çerçeve içerisinde yürütülmesine müsaade etmiştir (Çınar, 2014: 222). Merkez siyaset olarak ifade edilen bu çerçeve, elitist anlayışla örtüşen ve bu yapıyla iktidarı paylaşmayı öngören siyaset anlayışıdır. Siyasetin sınırlarının ve şartlarının belirlendiği bu çerçevede serbest seçimlerle hükmetme hakkını elinde bulunduran iktidarların kurucu siyaset yerine uygulayıcı siyaset yapmalarına müsaade etmişlerdir ve bu çerçevenin dişına çıkma veya çıkma girişiminde bulunma ise demokrasinin kesintiye uğraması anlamına gelmiştir.

Sonuç olarak Türkiye demokrasisi gözden geçirildiğinde; elitist bir demokrasi anlayışı ve bunun işlerliğini sağlayan vesayetçi bir yapının varlığı göze çarpmaktadır. Bu çerçevede Türkiye demokrasisi üzerindeki temel tartışma konusu aslında demokrasinin vesayetçilik ve vesayetçilik karşıtlığ 1 arasında sıkışmış olmasıdır. Bu kısır döngü içerisindeki asıl tehlike ise vesayetçi yapıların baskısı ve etkinliği azaldıkça başka vesayetçi yapıların ortaya çıkma ihtimalidir. Çünkü demokratik meşruiyetin tek kaynağının seçimler ve çıkan sonuçlara bağlandığı bir iklimde bütün iktidarların temel özelliği olan genişleme özelliği birbiriyle ilişkilendirildiğinde Türkiye demokrasisinin yeni bir kısır döngü içerisine girme ihtimalinin varlığını her zaman koruduğu ifade edilebilir (Çınar, 2014). 


\section{Doğrudan Demokrasi Kurumu Olarak Türkiye'de Referandum}

İsviçre ve Amerika Birleşik Devletleri gibi doğrudan demokrasi kurumlarını kullanan ülkelerden farklı olarak Türkiye'de referandum, yalnızca anayasa değişikliklerinde başvurulan bir doğrudan demokrasi aracıdır. Ülkemizde anayasa yapımı ve anayasa değişiklikleri bakımından başvurulan bir kurum olan referandum 1961 yılından itibaren 7 kez yapılmıştır.

1961 ve 1982 Anayasaları anayasa yapım süreci ile ilgili referandumlar iken diğer beş referandum anayasa değişikliği için yapılan referandumlardır. 1961 ve 1982 anayasaları için yapılan referandumlar günümüz Türkiye'sinde genellikle gayri meşru olarak kabul edilmekte her ikisinde de askeri darbe hükümetlerinin seçmenleri zorlaması sonucunda çoğunluğun olumlu oyunun alındığı iddiası kabul görmektedir (Kalaycıŏlu, 2012: 68). İlk iki anayasa onayı mekanizması olarak kullanılan 1961 ve 1982 halkoylamalarından sonra beş halkoylaması daha yapılmıştır. Bunlar sırasıyla 12 Temmuz 1987 Siyasal Hakların İadesi (\%50,5 Evet) katılma oranı \%94, 25 Eylül 1988 Yerel Seçimlerin Erkene Alınması (\%35 Evet) katılma oranı \%89, 21 Ekim 2007 Cumhurbaşkanının Doğrudan Halkoyuyla Seçimi (\%69 Evet), katılma oranı \%68, 12 Eylül 2010 Anayasa Değişikliği Referandumu (\%58 Evet) katılma oranı \%74 (Kalaycığlu,2012:68) ve nihayet 16 Nisan 2017 Anayasa Değişikliği Referandumu (\%51,4 Evet) katılma oranı \%85,32 olan halkoylamalarıdır. 1961 yılından itibaren Türkiye'de toplam yedi halkoylaması yapılmıştır.

Referandum kavramı demokrasimize vesayetçi elitist yapıların hazırlamış olduğu 1982 Anayasası ile girmiş ve ilk şekliyle anayasada sadece ihtiyari referanduma yer verilirken 1987 yılında yapılan değişiklikle birlikte zorunlu referandum da demokrasimize yerleşmiştir (Şahbaz, 2006: 278).

Anayasamızın 175'inci maddesinin 4'üncü fikrasında, "Meclis üye tamsayısının beşte üçü ile veya üçte ikisinden az oyla kabul edilen Anayasa değişikliği hakkındaki Kanun, Cumhurbaşkanı tarafından Meclise iade edilmediği takdirde halkoyuna sunulmak üzere Resmî Gazetede yayımlanır" ibaresi geçmektedir. Bu ibareye göre zorunlu referanduma gidilebilmesi için; Teklifin Türkiye Büyük Millet Meclisi üye tamsayısının 3/5 ile 2/3'ü arasındaki bir oyla kabul edilmesi ve bununla birlikte Cumhurbaşkanı'nın kendisine gelen yasayı Meclise iade etmemiş olması gerekmektedir.

İhtiyari referandum yine aynı şekilde Anayasanın 175. maddesinin 3. fikrasında; Cumhurbaşkanı Anayasa değişikliklerine ilişkin kanunları, bir daha görüşülmek üzere Türkiye Büyük Millet Meclisine geri gönderebilir. Meclis, geri gönderilen Kanunu, üye tamsayısının üçte iki çoğunluğu ile aynen kabul ederse Cumhurbaşkanı bu Kanunu halkoyuna sunabilir şeklinde 5. fikrasında ise Doğrudan veya Cumhurbaşkanının iadesi üzerine, Meclis üye tamsayısının üçte iki çoğunluğu ile kabul edilen Anayasa değişikliğine ilişkin kanun veya gerekli görülen maddeleri Cumhurbaşkanı tarafından halkoyuna sunulabilir. Halkoylamasına sunulmayan Anayasa değişikliğine ilişkin Kanun veya ilgili maddeler Resmî Gazetede yayımlanır.

\section{Anayasa Yapımında Uygulanan Referandumlar}

Türkiye, ulusal düzeyde ilk referandum uygulaması ile ilk olarak 1961 Anayasa'sının kabulü ile tanışmıştır. Referanduma giden süreç içerisinde referandumun 
yapılıp yapılmaması noktasında görüş ayrılıkları oluşmuştur ve bu noktada özellikle Ankara Üniversitesi Siyasal Bilgiler Fakültesi'nin (SBF) hazırlamış olduğu anayasa tasarısında, anayasanın halkoyuna sunulmasının sakıncalı olacağı savunulmuştur. Bu görüşün karşısında duranlar ise; anti demokratik Demokrat Parti (DP) iktidarının sona ermiş olması ve ülkeye hâkim olan genel özgürlük havası düşünüldüğüne, halkın referandumda yeni anayasayı destekleyeceğini tahmin etmiştir. Bununla birlikte DP seçmenlerine oy hakkı verilmek suretiyle DP'nin anayasal yapım sürecindeki yokluğunun yarattığ 1 meşruiyet sorununun giderileceği ve referandumun yeni anayasanın gelecekteki hukuksallığının kuvvetlenmesinde büyük yararı olacağı savunulmuştur (Şahbaz, 2006: 249-251)

1961 referandumu sonuçları açısından değerlendirildiğinde; mevcut anayasaya karşı ilk günden itibaren toplumun bazı kesimlerinden kuvvetli muhalefet olmuştur. Bunun temel kanıtı olarak da Milli Birlik Komitesi'nin referandum sürecine tamamen hâkim olması ve Demokrat Parti'nin yeterli örgütlenmeyi sağlamamış olmasına rağmen \%40'a yakın bir hayır oyunun çıkması sayısal olarak hayli yüksek ve anlamlıdır. Bununla birlikte eleştirilerin diğer bir boyutu 1961 Anayasa'sının toplumun çoğunluğunun ortak mutabakatına göre oluşturulan bir toplum sözleşmesi niteliği kazanmadığı için toplum tarafından benimsenmediğidir (Özbudun, 2004: 45-46).

1961 Anayasası'nın yapım sürecinde fiiliyatta olmasa bile teorideki demokratik ve sivil niteliğine karşın,1982 Anayasası tartışmasız bir biçimde anti demokratik yöntemlerle kabul edilmiştir. 1982 Anayasası halkoylaması sürecinde Milli Güvenlik Kurulu'nun almış olduğu kararlarla feshedilmiş olan siyasi parti yönetici kadrosunun görüş bildirmeleri ve daha da ileri gidilerek bunların Türkiye'nin geçmiş ve geleceği ile ilgili yorum yapmaları da yasaklanmıştır (Şahbaz, 2006: 259-260). Bu tedbirlere ilaveten Devlet Başkanı'nın görsel medya ve gezilerinde anayasa tanıtımına ilişkin yapacağı konuşmaların eleştirilmesi de yasaklanmıştır. Bahsedilen önlemlerle anayasaya karşı kampanya yürütme olasılığı tamamen ortadan kaldırılmıştır.

Sonuç olarak 1982 Anayasası değerlendirilirken plebisit ve referandum arasındaki farkın bu anayasa ile kendisini gösterdiği görülmektedir. Referandum sürecinde seçmenler üzerinde baskıcı ortam oluşturan uygulamalara gidilmesi, eleştiri ortamının garanti altına alınmasının aksine eleştirmemenin güvence altına alınması 1982 Anayasasının referandum yerine plebisit olarak değerlendirilmesi gerektiğini göstermektedir.

\section{Anayasa Değişikliklerinde Uygulanan Referandumlar}

Günümüze kadar gerçekleşen anayasa değişikliklerinde beş kez referanduma başvurulmuştur. Bunlardan ilki 1987 yılında yapılan referandumdur. 1987 referandumunun konusu siyasal yasakların düzenlenmiş olduğu 1982 Anayasa'sının geçici dördüncü maddesinin yürürlükten kaldırılmasıdır (Şahbaz, 2006: 270-271). Siyasal yasakların kaldırılmasına karşı olan fakat buna direnemeyeceğinin farkında olan Turgut ÖZAL, değişiklikleri ${ }^{5}$ reddedilir umuduyla referanduma götürme kararı almıştır ve red

5 17.5.1987 tarih 3361 Sayılı Kanun (R.G.18.5.1987 Sayı 19464 Mük.) ile kabul edilen Anayasa Değişiklikleri şu şekilde özetlenebilir: Anayasa Seçmen yaşının düşürülmesi, 12 Eylül yönetimince yasaklanan siyasetçilerin siyaset yasaklarını düzenleyen anayasanın geçici dördüncü maddesinin kaldırılması, milletvekili sayısının arttırılması ve anayasa değișiklik usulünde değişiklik yapılması; 6 Eylül 
yönünde kampanya yürütmesine rağmen, değişiklikler referandumla kabul edilmiştir. Referandum içeriğine bakıldığı zaman aslında referandumun ruhu ile bağdaşmayan bir durum ortaya çıkmaktadır. Siyasal yasaklar zaten kendiliğinden demokrasi ile bağdaşmayan ve demokrasinin temel niteliklerinden biri olan seçme ve seçilme hakkına müdahaledir $\mathrm{Bu}$ durumun referandum yoluyla kaldırılmak istenmesi mevcut ortamda ismen bir demokrasi varlığından bahsedilse bile toplumsal bilinç ve kültür anlamında bir demokrasi ve demokratik değer yoksunluğunun göstergesidir

1988 yılında yapılan anayasa değişikliği referandumu, Türkiye'de yapılan ikinci anayasa değişikliği referandumudur. Referandumun konusu 1982 Anayasa'sının 127. maddesinde yer alan yerel seçimlerin beş yılda bir yapılacağını düzenleyen hükmün değiştirilmesidir. Belirtilen amaçla yapılan referandum, Türkiye'de yapılan en anlamsız referandum olarak nitelendirilmektedir ve nitekim bu referandum olumsuz sonuçlanmıştır (Tanör \& Yüzbaş1oğlu, 2004: 52).

1987 ve 1988 referandumları Anavatan Partisi (ANAP) Hükümetinin başarısızlığı olarak ifade edilmektedir. Her iki halkoylamasında da Turgut ÖZAL ve ANAP iktidarı sorgulanmış ve halkoylaması bir nevi iktidar için güven oylaması niteliğine bürünmüştür. Referandum konusunun aşırı derecede politize olması ve muhalefet partilerinin anayasa değişikliğine karşı kararlı bir biçimde cephe almış olmasının ANAP'ın seçmenleri kendi siyasi tercihleri doğrultusunda yönlendirememiş olmasındaki rolü büyüktür (Özbudun, 2004: 155).

1982 Anayasası çerçevesindeki üçüncü referandum 21 Ekim 2007 tarihinde yapılmıştır. Bu referanduma konu olan anayasa değişikliği ${ }^{6}$, cumhurbaşkanının doğrudan halk tarafından seçilmesi usulünü Türk Anayasa sistemine getirmiştir. Cumhurbaşkanı seçim usulünde gerçekleşen bu değişiklik, Türkiye'nin hükümet sistemi olan parlamenter sistemi yarı başkanlık sistemine dönüştürmüştür (Yücel, 2009: 255-257). 21 Ekim 2007'de yapılan halkoylamasıyla cumhurbaşkanlarının o tarihten sonra doğrudan halkoyuyla ve iki turlu bir seçimle beş y1l için ve bir kere yenilenebilir biçimde seçilmesi ilkesi kabul edilerek, Türkiye'de uygulanan demokratik rejimin niteliğini kökten değiştirecek bir adım atılmıştır. Artık hem TBMM'yi, hem de cumhurbaşkanını halkın seçtiği bir demokrasi uygulaması yürürlüğe konmuştur. Ancak, cumhurbaşkanının statüsü 1982 Anayasasında belirtilen yetkiler çerçevesinde kalırken hem halkoyuyla iki defa seçilebilen hem de siyasal ve hukuki sorumsuzluğu devam eden bir garip cumhurbaşkanlığı mevkii ortaya çıkmıştır. Bu durumda 21 Ekim 2007 halkoylamasını, bir rejim değiştirici seçmen eylemi olarak kabul etmek ve böylece adeta daha önceki halkoylamaları gibi anayasa onayan bir içerikte olduğunu ileri sürebilmek de mümkündür(Kalaycıŏlu, 2012: 69). 21 Ekim 2007 referandumu, tek bir oyla birden fazla değişikliğin oyladığı bir referandum olması sebebiyle eleştirilmektedir. Burada eleştirilen husus, seçmenlerin istedikleri bir değişikliğin kabulü için belki istemeyecekleri bir

$1987^{\text {ee }}$ de gerçekleştirilen referandumun sonuçlarını bildiren Yüksek Seçim Kurulu Kararı: No 398, Resmi Gazete,12.91.1987, Say1,19572

${ }^{6}$ Anayasa değişikliği üç önemli yenilik getirmiştir. Birincisi Meclis yasama döneminin beş yıldan dört yıla indirilmesidir. İkincisi Meclis toplantı yetersayısının her durumda üye tamsayısının üçte biri (184) olduğunun Anayasaya eklenmesi, üçüncü ve en önemli değişiklik ise cumhurbaşkanını halkın seçmesini sağlayan düzenlemedir. $\mathrm{Bu}$ düzenlemeyle cumhurbaşkanının doğrudan halk tarafindan seçilmesi öngörülmüş, görev süresi beş yılla sınırlanmış, aynı kişinin iki defa seçilebilmesi mümkün kılınmıştır. 5678 sayılı Kanun metni için Bkz (URL-1) 
değişikliğe de "Evet" demek zorunda bırakılmalarıdır. Halkın önemli bir anayasa değişikliği konusunda yeterli düzeyde bilgilendirilmeden, değişikliklerin getirecekleri ve götürecekleri tartışılmadan referanduma gidilmiş olması da eleştirilmektedir. 2007 referandumunun asıl amacının Anayasa Mahkemesi'nin kararını etkisiz hale getirmek ve iktidar partisinin cumhurbaşkanı adayını halka seçtirmek olarak değerlendirilmiştir (Akbulut, 2010: 1560). Mevcut hükümetin bu amacını gerçekleştirmek için referandum metni ve kanunlar üzerinde çok fazla değişiklik yapması 2007 referandumuna giden sürecin belirgin özelliğini oluşturmaktadır. Bu bağlamda sürekli değișen düzenlemeler seçmeni bir oldu-bitti karşısında bırakmış ve referandumun plebisite dönüşmesine yol açmıştır (Batum, 2009: 87).

2007 Referandumu teknik açıdan plebisit unsurlarını taşımakla birlikte Türk demokrasisinde egemen olan vesayetçi yapı ve bunun yansıması olan Anayasa Mahkemesinin skandal olarak nitelendirilen 367 kararı, siyasetin kriz içerisine girdiğini açıkça göstermektedir. Bu kriz ortamından çıkmak ve vesayetçi yapıyı kırmak amacıyla demokrasinin önemli araçlarından biri olan referanduma gidilmesi o zamanki koşullar açısından tek çıkar yol olarak değerlendirilebilir.

Anayasa değişikliğine ilişkin dördüncü referandum 12 Eylül 2010 tarihinde gerçekleşmiş ve bu referandumda mevcut anayasanın toplam 26 maddesinin değiştirilmesinin öngörüldüğ $\ddot{u}$ 07.05.2010 tarih ve 5982 sayılı kanun oylanmıştır. Bu referandumda \%57.88 oranında evet oyu çıkmış ve söz konusu kapsamlı anayasa değişikliği kabul edilmiştir ${ }^{7}$. 12 Eylül 2010 halkoylaması aslında yargı üzerindeki yürütme vesayetini tesis etmeye yönelik anayasa değişikliği olarak ortaya çıkmıştır. Bunun vatandaşa sunumu yapılırken yargıyı demokratikleşme olarak tanıtılmış fakat fiilen Adalet Bakanlığı'nın Hakimler ve Savcılar Yüksek Kurulu seçimlerine ağırlık koymasıyla, bu bakanlığın bürokrasi denetimine giren yargı gücü ortaya çıkmıştır. Bu düzenlemenin dışında bir takım değişiklikler kabul edilmiş olmasına rağmen hiçbirinin demokrasinin kalitesini arttıran kalıcı siyasal etkileri olmamıştır (Kalaycıoğlu, 2012: 71).

2010 referandumu içerisinde barındırdığı unsurlar nedeniyle aslında olumlu karşılanan bir takım düzenlemenin hayata geçmesini sağlamıştır. Bununla birlikte hayata geçen düzenlemeler özellikle Avrupa Birliği Komisyonu, Avrupa Konseyi Venedik Komisyonu tarafindan demokratikleşme yönünde olumlu adımlar olarak değerlendirilmiştir (Özbudun, 2015: 110). Burada temelde eleştirilen nokta ise elde edilen kazanımların tek tek değiştirilerek vesayetçi yapıya karşı yeni bir vesayetçi yapının kurulup kurulmamak istenmesi durumudur. 2011 yılından sonra örneğin polis yetkililerinin gizli soruşturmalar hakkında mülki idare amirlerine bilgi vermek zorunda bırakılmaları, 2014 yılında HSYK yapısında yürütme lehine düzenlemeler yapılması, Sulh Ceza Hakimliklerinin kurulması, 2012 yılında Yargıtay ve Danıştay yapılarının değiştirilmesi (Özbudun, 2015: 112-116) yargının yürütme denetimi altına alınması olarak değerlendirilmiştir. $\mathrm{Bu}$ çerçevede akla gelen temel soru vesayetçi yapıların etkinliği kırılırken demokrasinin yeniden vesayetçi ve vesayetçi karşıtlı̆̆ bağlamında kısır döngü içerisine girip girmeyeceği hususudur.

${ }^{7}$ 07.05.2010 tarih ve 5982 sayılı Kanun: Resmi Gazete, 13.05.2010, Sayı: 27580. Referandum sonuçlarına ilişkin YSK kararı: Karar no 846, K.T.22.09.2010. (URL-2) 
Nihayet beşinci referandum 16 Nisan 2017 tarihinde gerçekleşmiş bu referandumda anayasanın toplam 18 maddesinin değiştirilmesinin öngörüldüğü 21.01.2017 tarih ve 6771 sayılı kanun oylanmıştır. Bu referandumda \%85.43 oranında katılım sağlanmış ve \%51,41 oranında evet oyu çıkmış ve söz konusu kapsamlı anayasa değişikliği kabul edilmiştir ${ }^{8}$. 16 Nisan 2017 tarihinde yapılan referandum hem sonuçların meşruiyeti hem de yapılış biçimi noktasında eleştirilmektedir. Referandumun OHAL süreci içerisinde yapılması, alternatif medya unsurlarının kapatılması ve alternatif bilgiye ulaşımın kısıtlanması ve süreçte siyasal iktidarın devlet kaynakları ile rekabette avantajlı konumda bulunması vb. unsurlar demokrasinin özü ile bağdaşmayan unsurlar olarak ön plana çıkmaktadır. Sonuç noktasında ise özellikle Yüksek Seçim Kurulu'nun seçim esnasında almış olduğu karar oyun oynanırken kural değiştirilmez ilkesinin ihlali olmuştur. Referanduma getirilen diğer bir eleştiri referandumun hem iktidar hem de muhalefet tarafindan meydan okuma ve güven tazeleme unsuru olarak görülmesi ve bu nedenden dolayı referandumun özünden ziyade evet ve hayır şeklinde bir cepheleşmenin ortaya çıkması olarak tezahür etmiştir. Bu tezahür aynı zamanda torba yasa şeklinde olan ve içinde birçok maddeyi barındıran referandumun halk tarafından içeriği bilinmeden oylanmasına neden olmuştur. Referandumun hazırlanış sürecinde ve ortaya çıkan sonuca bakıldığında demokrasi anlayışının çoğulcu demokrasi olarak benimsendiği çağımızda ülkemizde hala çoğunlukçu demokrasi anlayışının hâkim olduğu görülmektedir ve toplumsal mutabakatın sağlanmadığı bir referandum ancak plebisit olarak nitelendirilebilir.

\section{SONUÇ}

Tarihsel ve düşünsel anlamda doğrudan demokrasi, Antik Yunan site devletlerinde uygulanmaya başlanmış fakat bu site devletlerin ortadan kaybolup İmparatorluk birimlerinin birer parçası olmalarıyla birlikte uzunca bir süre unutulan ve üzerinde konuşulmayan bir yönetim modeli haline gelmiştir. XVIII. yüzyılda Rousseau'nun egemenliğin devredilmezliği düşüncesi ekseninde yeniden gündeme gelen doğrudan demokrasi uygulamaları kendine özellikle devrim sürecinde hazırlanan anayasalarda yer bulmuştur. Uygulama şansı olmayan bu anayasalardan sonra temsili kurumlara yer veren demokrasi anlayışı benimsenmiş ve buna uygun anayasalar yapılmıştır. Bunun sonucunda doğrudan demokrasi uygulamaları yeniden geri planda kalmaya başlamıştır. Günümüzde İsviçre ve Amerika Birleşik Devletleri'nde, doğrudan demokrasi uygulamalarında XVIII. Yüzyıldaki gelişmelerden ilham alarak, doğrudan demokrasi araçları ve dolayısı ile referandum uygulamaları etkin bir biçimde kullanmaktadırlar.

Genel olarak doğrudan demokrasi özelde ise referandum aracılığı ile halkın devlet yönetimine etkin bir şekilde katılması gerektiğini öne süren düşünürler; doğrudan demokrasi araçlarıyla alınan siyasi kararların halkın gözündeki meşruluğunu en üst seviyeye çıkaracağı varsayımını ön planda tutmaktadır. Bununla birlikte doğrudan demokrasi araçları sayesinde vatandaşlar siyasi konularla daha içli dışlı olacak ve bu da halkın toplumsal sorunlara dair eğitilmelerine olanak sağlayacaktır. Son olarak, bir siyasi sistemde doğrudan demokrasi araçlarının varlığı, temsil kurumlarının siyasi kararları alırken daha dikkatli olmasını ve vatandaşların görüşlerini dikkate almasını sağlayacaktır 
(Cohen \& Sabel, 1997). Çünkü kabul edilen bir kanunun referanduma sunulma ihtimali bile yasama organlarını kanunları olası bir referandumda kabul edilecek bir şekilde hazırlamaya yöneltecektir. Doğrudan demokrasi aleyhine söz söyleyen düşünürler ise öncelikle kanun yapmak gibi önemli bir konuda bilgisiz halk kitlelerinin belirleyici olmasını sakıncalı bulmaktadır. İkinci olarak birçok gözlemci, bir toplumda sık sık halkoylamasına başvurulmasının seçmenlerde bıkkınlık ve ilgisizlik yaratmasına işaret etmektedir. Böyle durumlarda referandum olgusu seçmenlerin gözünde siradanlaşmakta ve bu nedenle halk bu kuruma yabancılaşmaktadır. Bu tür görüşler, doğrudan demokrasi araçlarının etkin bir şekilde kullanıldığı İsviçre gibi ülkelerde halkoylamalarına ortalama katılımın \%30 gibi düşük bir seviyede gerçekleşmesi olgusuna dayanmaktadır.

Özet olarak belirtmek gerekirse doğrudan demokrasiyi savunan görüşler meşruiyet ve halkın rızası ve katılımı ortak paydalarında buluşurken temsili demokrasiyi savunan görüşler istikrar, 1lımlılık ve uzlaşma gibi kavramlar üzerine vurgu yapmaktadırlar. Bu bağlamda her iki düşünceyi savunanlar da eşit seviyede inandırıcılık argümanlarına sahiptir denilebilir ve bu çerçevede referandum müessesesini temsili demokrasinin alternatifi olarak görmek yerine, temsili demokrasiyi iyileştirici ve düzenleyici bir kavram olarak algılamak daha uygun olacaktır. Referandum noktasında işlevsel anlamda önemli olan olgu temsili demokrasi içerisinde parlamenter çoğunluğun iktidarını yumuşatmak amacıyla referandum uygulamasına başvurulmasıdır.

Demokratik yönetim anlayışı çerçevesinde ülkeler kendi anayasalarında referandumun hangi konularda ve hangi yöntemle uygulanacağını belirtme yoluna gitmişlerdir. Burada önemli olan husus ise referendum yoluyla halkın yönetime doğrudan katılımı kavramını amaçlayan uygulamanın çokluğun azlık üzerindeki baskı mekanizması olarak kullanılmamasıdır. $\mathrm{Bu}$ nedenle referandumun siyasi sistem içerisindeki yeri ve ağırlı̆ğnın hassas bir şekilde belirlenmesi gerekmektedir.

Nihayetinde Referandum demokratik standartlar çerçevesinde kullanıldığı zaman demokratikleşmeye katkı sağlayan önemli bir araçtır. Portekiz ve Yunanistan'da 1974, İspanya'da ise 1976 yıllarında diktatörlük yönetimlerinin yıkılması ve sonrasında yeni anayasanın referandumla kabul edilmesi referandumların bu ülkelerin demokratikleşmesi sürecinde halkın meşruiyetini alma bağlamında önemli bir araç olarak görülebilirken doğrudan demokrasinin beşiği sayılan İsviçre'de 2009 yılında yapılan referandum ile ülkede minare inşasının yasaklanmasının ${ }^{9}$ ne demokrasi ile ne de demokratikleşme ile ilgisi olduğunu söylemek mümkün değildir. Çünkü demokrasi, çoğunlukçu demokrasi anlayışı çerçevesinde ele alındığında alınan karar halk iradesinin gerçekleşmesi açısından demokratik bir eylem olarak görülebilir. Fakat olaya çoğulcu demokrasi, insan hakları veya özgürlükler açısından bakıldığında referandumlar çoğunluk iradesinin yansıması bakımından demokratik bir yöntem olsa bile özgürlükleri arttırma veya insan hakları açınsan olumsuz sonuçlar doğurabilme potansiyeline sahip olabilmektedir. Referandumların başlı başına bir demokratikleşme aracı olmadığını sadece süreç içerisinde kullanılan bir argüman olduğunu ve bu nedenle sınırlarının İsviçre' deki minare uygulamasında olduğu gibi popülizme yol açmayacak biçimde belirlenmesi gerektiği göz

\footnotetext{
9 İsviçre'de yeni minare yapımına yasak getirilip getirilmeyeceğine karar vermek amacıyla düzenlenen referandumda, seçmenin yüzde 57'den fazlası yasağa destek verdi. Referandumun kesin sonuçlarına göre, konfederasyonu oluşturan 26 kantondan sadece dördü bu yasağa karşı çıktı. Bkz: (URL-5)
} 
önünde bulundurulmalıdır. Bununla birlikte referendum, demokrasinin bir arac1 görülmekle birlikte hassas dengesi nedeniyle uygulamada seçmenlerin görüşlerinin alınmaması ve süreçten habersiz bırakılması referandumları bazen demokratik olmayan uygulama biçimine dönüştürebilmektedir. Referandumun yapılış sürecinde vatandaşların ve temsilcilerin karşılıklı katılımı söz konusu değilse ortaya çıkan sonuç seçmenin görüşünün tezahüründen ziyade referanduma konu olan soruyu ortaya atanın görüşünü yansıtmaktan öteye geçemez. Bu nedenden dolayı referandumun demokrasinin bir aracı ve demokratikleşme sürecinin bir safhası olarak değerlendirebilmek için gündem konusunun belirlenmesi ve şekillenmesi aşamalarında temsilcilerin ve seçmenlerin karşılıklılık ilişkisi çerçevesinde sürece dâhil olmaları gerekmektedir. Bunun aksine bir süreçte gerçekleşen referandum için demokrasinin bir uygulama aracı yerine siyasetin bir uygulama aracı olarak bakmak daha anlamlı olacaktır.

\section{KAYNAKÇA}

Akbulut, O. (2010). “Bir Doğrudan Demokrasi Kurumu Olarak Referandum”, Prof. Dr. Ali Güzel'e Armă̆an, C: II. İstanbul: Beta Yayıncılık.

Aktan, C. C. (1997). Yeni Sivil Toplum Sözleşmesi. Sivil Toplum-Yeni Türkiye Dergisi(18).

Aktaş, M. (2015). Demokrasi Kavramına Eleştirel Bir Bakış. Anemon Muşs Alparslan Üniversitesi Sosyal Bilimler Dergisi, 3(1), 87-105.

Altman, D. (2011). Direct Democracy Worldwide. New York: Cambridge University Press.

Aristoteles. (2010). Politika (M. Tunçay, Trans.). İstanbul: Remzi Kitabevi.

Batum, S. (2009). 99 Soruda Neden ve Nasıl Çağdaş Bir Anayasa. İstanbul: XII Levha Yayınları.

Bostanc1, N. (1995). Toplum, kültür ve siyaset. İstanbul: Vadi Yayınlar1.

Bulut, N. (2003). "Kapitalizm-Demokrasi İlişkisi (Demokrasinin Ekonomik Temelleri Üzerine Bir İnceleme)”. Erzincan Hukuk Fakültesi Dergisi, VII(1-2), 69-88.

Cohen, J., \& Sabel, C. (1997). Directly-Deliberative Polyarchy. European Law Journal, 3(4), 313-342.

Cronin, T. E. (1989). Direct Democracy. The Politics of Initiative, Referendum, and Recall. Cambridge: Harvard University Press.

Çaha, Ö. (2012). Demokrasi. In H. Çetin (Ed.), Siyaset Bilimi (3. ed., pp. 221-265). Ankara: Orion Kitabevi.

Çınar, M. (2014). Demokrasi. In Y. Taşkın (Ed.), Siyaset, Kavramlar, Kurumlar, Süreçler (pp. 203-251). İstanbul: İletişim Yayınları.

Dahl, R. A. (2001). Demokrasi Üstüne (B. Kadığlu, Trans.). Ankara: Phoenix Yayınevi.

Göze, A. (2017). Siyasal düşünceler ve yönetimler (17. ed.). İstanbul: Beta Basım Yayım Dağıtım A.Ş.

Gözler, K. (1998). Halkoylamasının Değeri. Ankara Üniversitesi Hukuk Fakültesi Dergisi, 50(1-4), 97-113. 
Gözler, K. (2007). Anayasa hukukuna giriş: genel esaslar ve Türk anayasa hukuku. Bursa: Ekin Kitabevi.

Gözler, K. (2014). Kısa Anayasa Hukuku (11. ed.). Bursa: Ekin Yayınları.

Held, D. (2006). Models of democracy (3. ed.). Carnbridge: Polity Press.

Heywood, A. (2014). Siyaset (B. Şahin, B. Özipek, M. Yıldız, \& A. Yayla, Trans. 14. ed.). Ankara: Adres Yayınları.

Holden, B. (2007). Liberal Demokrasiyi Anlamak (H. Bal, Trans.). Ankara: Liberte Yayınları.

Hug, S. (2009). Some thoughts about referendums, representative democracy, and separation of powers. Constitutional Political Economy, 20(3), 251-266.

Huntington, S. (1993). Üçüncü Dalga: Geç Yirminci Yüzyılda Demokratikleşme (E. Özbudun, Trans.). Ankara: Türk Demokrasi Vakfı Yayınları.

Kahraman, H. B. (2008). Türk Siyasetinin Yapısal Analizi I: (Kavramlar, Kuramlar, Kurumlar). İstanbul: Agora Kitaplığı.

Kalaycığlu, E. (2012, 23-24 Haziran). Türkiye'de Halkoylamalarl: Katılma mı, Yürütme Vesayeti mi? Paper presented at the Demokrasi ve Siyasal Katılım, İstanbul.

Kışlalı, A. T. (1984). Eski Yunan'da demokrasi ve demokratik düşünce. Amme İdaresi Dergisi, 17(1), 63-77.

Köker, L. (2008). Demokrasi, Eleştiri ve Türkiye. Ankara: Dipnot Yayınları.

Kubal1, H. N. (1971). Anayasa hukuku dersleri: genel esaslar ve siyasi rejimler. İstanbul: İstanbul Üniversitesi, Hukuk Fakültesi.

Kużelewska, E. (2009). The impact of referendums on the process of European integration. Baltic Journal of Law \& Politics, 2(2), 181-200.

Laski, H. J., \& Strachey, J. (1962). Demokrasi Nedir? Sosyalizm Nedir? (N. Hersek, Trans.). İstanbul: Evren Yayınları.

Lorch, R. S. (1992). State \& Local Politics: The Great Entanglement (4. ed.). New Jersey: Prentice Hall Inc.

Miller, D., Coleman, J., Connolly, W., \& Ryan, A. (1994). Blackwell'in Siyasal Düşünce Ansiklopedisi (B. Peker \& N. Kıraç, Trans.). Ankara: Ümit Yayıncılık.

Mishin, A. (1996). Constitutional (state) right of the foreign countries. Moskow: White Alvah.

Özbudun, E. (2004). Türk Anayasa Hukuku (8. ed.). Ankara: Yetkin Yayınları.

Özbudun, E. (2015). Anayasacılık ve Demokrasi (1. ed.). İstanbul: İstanbul Bilgi Üniversitesi Yayınlar1.

Platon. (2001). Devlet (C. Saraçoğlu \& V. Atayman, Trans.). İstanbul: Bordo Siyah Yayınları.

Qvortrup, M. (2015). A Tale of Two Referendums Elite Manipulation or Civic Engagement. London: The Constitution Society. 
Qvortrup, M. (2017). The rise of referendums: Demystifying direct democracy. Journal of democracy, 28(3), 141-152.

Qvortrup, M. (2018a). Introduction: Theory, Practice and History. In M. Qvortrup (Ed.), Referendums Around the World: With a Foreword by Sir David Butler (pp. 1-19). Coventry: Palgrave Macmillan.

Qvortrup, M. (2018b). Two Hundred Years of Referendums. In M. Qvortrup (Ed.), Referendums Around the World: With a Foreword by Sir David Butler (pp. 263273). Gewerbestrasse: Palgrave Macmillan.

Reilly, B. (2003). Democracy in divided societies: Electoral engineering for conflict management. , New York: Cambridge University Press.

Rousseau, J.-J. (2006). Toplum sözleşmesi (V. Günyol, Trans.). İstanbul: Türkiye İş Bankası Kültür Yayınları.

Schmidt, M. G. (2002). Demokrasi kuramlarına giriş (M. E. Köktaş, Trans. 2. ed.): Vadi yayınları.

Setälä, M. (1999). Referendums and democratic government: normative theory and the analysis of institutions. London: Macmillan Press Ltd.

Suksi, M. (1993). Bringing in the people: A comparison of constitutional forms and practices of the referendum: Martinus Nijhoff Publishers.

Şahbaz, İ. (2006). Yarı Doğrudan Demokrasi Kurumu Olarak Referandum ve Türkiye. Ankara: Yetkin Yayınları.

Şenel, A. (2002). Siyasal Düşünceler Tarihi (10. ed.). Ankara: Bilim ve Sanat Yayınları.

Tannenbaum, D. G., \& Schultz, D. (2015). Siyasi Düşünce Tarihi Filozoflar ve Fikirleri, çev (F. Demirci, Trans. 9. ed.). Ankara: Adres Yayınları.

Tanör, B., \& Yüzbaşığlu, N. (2004). 1982 Anayasasına Göre Türk Anayasa Hukuku (5. ed.). İstanbul: Yapı Kredi Yayınları.

Teziç, E. (1998). Anayasa Hukuku (5. ed.). İstanbul: Beta.

Tosun, G. (2001). Demokratiklesme Perspektifinden Devlet-Sivil Toplum Iliskisi. İstanbul: Alfa Yayınları.

Uslu, A. (2014). Demokrasi. In G. Atılgan \& E. A. Aytekin (Eds.), Siyaset Bilimi (Kavramlar, İdeolojiler, Disiplinler Arası İlişkiler) (4. ed., pp. 137-153). İstanbul: Yordam Kitap.

Uygun, O. (2003). Demokrasinin tarihsel felsefi ve ahlaki boyutlart. İstanbul: İnkilap Kitabevi.

Yayla, A. (2012). Anayasacılık, Anayasal Demokrasi ve İdeolojiler. Liberal Düşünce Dergisi(66), 13-22.

Yücel, B. (2009). Parlamenter Hükümet Sisteminin Rasyonelleştirilmesi ve Türkiye Örneği. Ankara: Adalet Yayınevi. 


\section{ELEKTRONİK KAYNAKLAR}

URL-1 http://www.tbmm.gov.tr/kanunlar/k5678.html (Erişim Tarihi: 08.06.2017)

URL-2 http://www.ysk.gov.tr/ysk/faces/Kararlar?_adf.ctrl (Erişim Tarihi: 08.06.2017)

URL-3 http://www.resmigazete.gov.tr/eskiler/2017/02/20170211-1.htm (Erişim Tarihi: 09.06.2017)

URL-4 http://www.ysk.gov.tr/ysk/faces/Kararlar?_adf.ctrl- (Erişim Tarihi: 09.06.2017)

URL-5 http://www.cnnturk.com/2009/dunya/11/29/isvicre.minare.yasagina.evet.dedi/55350 9.0/index.html (Erişim Tarihi: 12.06.2017) 